\title{
ZÁKLADNÉ PRÁVO JEDNOTLIVCA NA ÚČINNÚ SÚDNU OCHRANU UPRAVENÉ V ČLÁNKU 47 CHARTY ZÁKLADNÝCH PRÁV EÚ A MOŽNOSTI JEHO UPLATNENIA V KONANIACH PRED SÚDMI EURÓPSKEJ ÚNIE
}

\author{
DOMINIKA BECKOVÁ
}

\begin{abstract}
The fundamental right to an effective judicial protection enshrined in Art. 47 of the Charter of Fundamental Rights of the $\mathbf{E U}$ and its application by individuals before Courts of the EU

The effective judicial protection is nowadays an essential element of national legal orders, as well as of European Law, in so far as it allows individuals to enforce their rights and obtain redress. Conferring of an increasing number and content of rights that the European Union guarantees to individuals, it is necessary to create a complex system of EU legal remedies, which will ensure an effectiveness of enforcement of EU rights. The aim of the article is to introduce a legal basic and summarise essence of the fundamental right to an effective judicial protection enshrined in Art. 47 of the Charter. The author is focusing on individual's options of application of its fundamental right to an effective judicial protection before courts of the EU. Before the Court of Justice of EU is the author focusing on preliminary rulings and proceedings based on Art. 263 (4) TFEU, and at the national level is the attention focused on the principle of national procedural autonomy, as one of key principles governing the enforcement of individuals rights guaranteed by Union law before national courts.
\end{abstract}

Keywords: the fundamental right to an effective judicial protection; the Court of Justice of the EU; national courts; procedural autonomy; sincere cooperation

Kl'účové slová: základné právo na účinnú súdnu ochranu; Súdny dvor EÚ; vnútroštátne súdy; procesná autonómia; lojálna spolupráca

DOI: $10.14712 / 23366478.2018 .43$

\section{1. ÚVOD}

Základné právo na účinnú súdnu ochranu je v dnešnej spoločnosti súčast'ou všetkých demokratických právnych poriadkov a predstavuje jadro ochrany všetkých ostatných práv priznaných jednotlivcom. Svoje právne zakotvenie nachádza vo väčšine vnútroštátnych, nadnárodných i medzinárodných katalógoch základných práv, nakol'ko je jeho obsahom právo na vymožitel'nost' práva a prístup k spravodlivosti, bez existencie ktorých by právo samotné stratilo svoj zmysel. Inak tomu nie je ani na úrovni Európskej únie, pretože Únia sama priznáva jednotlivcom množstvo práv, ktorých okruh sa neustále rozširuje. Predpokladom, ako efektívne zabezpečit' základné právo na účinnú súdnu ochranu v práve Únie bolo vytvorenie systému účinných prostriedkov 
nápravy pred súdom a spravodlivého súdneho konania pred súdom stanovenej kvality. ${ }^{1}$ V aktuálnom právnom prostredí Európskej únie je základným pilierom skúmaného základného práva článok 47 Charty základných práv EÚ (d’alej len ako „Charta“), ktorý priznáva každému, koho práva a slobody zaručené právom Únie sú porušené, právo na účinný prostriedok nápravy pred súdom. Tomuto právu zodpovedá povinnost' uložená členským štátom priamo v článku 19 ods. 1 druhom pododseku Zmluvy o Európskej únii (d’alej len ako „ZEÚ“") ustanovit’ v oblastiach, na ktoré sa vzt’ahuje právo Únie, prostriedky nápravy potrebné na zabezpečenie účinnej právnej ochrany. Táto povinnost' členských štátov bola do textu primárneho práva zavedená až Lisabonskou zmlvou a v aktuálnom právnom prostredí EÚ predstavuje d’alší vel'mi dôležitý pilier účinnej súdnej ochrany práv jednotlivcov.

Subjektmi povinnými zabezpečit účinnú súdnu ochranu práv jednotlivcov sú súdy Európskej únie, medzi ktoré patria všetky vnútroštátne súdy členských štátov a Súdny dvor EÚ, ktorý v súčasnosti tvorí Súdny dvor a Všeobecný súd. Vnútroštátne súdy členských štátov a Súdny dvor EÚ plnia pri zabezpečovaní účinnej súdnej ochrany práv jednotlivcov nenahraditel'nú úlohu a ich vzájomny vzt'ah je potrebné skúmat' v rámci decentralizovaného systému súdnej moci v EÚ, v ktorom vnútroštátne súdne orgány členských štátov primárne zabezpečujú ochranu práv jednotlivcov stanovenú a požadovanú právom Únie, a Súdny dvor Európskej únie je súdnym orgánom, ktorý svojím výkladom čl. 47 Charty presne stanovuje rozsah poskytovanej ochrany. ${ }^{2} \mathrm{~V}$ súlade so zásadou lojálnej spolupráce, obsiahnutej v čl. 4 ods. 3 Zmluvy o Európskej únii sú vnútroštátne súdne orgány členských štátov a Súdny dvor EÚ povinné pri zabezpečovaní účinnej súdnej ochrany jednotlivcov spolupracovat' a zabezpečovat' jej plné poskytnutie, s čím súvisí aj existencia princípu národnej procesnej autonómie.

Predkladaný článok si kladie za ciel' objasnit' aktuálnu právnu úpravu základného práva na účinnú súdnu ochranu v rámci práva Únie, poukázat’ na možnosti jednotlivca v konaniach pred Súdnym dvorom EÚ a v konaniach pred vnútroštátnymi súdnymi orgánmi pri aplikácií svojho základného práva na účinnú súdnu ochranu.

\section{2. ČLÁNOK 47 CHARTY ZÁKLADNÝCH PRÁV EÚ ALEBO ROZSAH SÚDNEJ OCHRANY PRÁV JEDNOTLIVCA}

Otázka vymožitel'nosti práva zohrávala dôležitú právnu a politickú otázku už v minulosti a to ako na úrovni vnútroštátnej, tak aj na úrovni nadnárodnej. ${ }^{3}$ Pri vytváraní jednotlivých právnych poriadkov sa do popredia dostávala myšlienka, že je

1 RAVO, L. M.: The role of the Principle of Effective Judicial Protection in the EU and its Impact on National Jurisdictions. In: Sources of Law and Legal Protection, (Triestine Lecture; 1), EUT Edizioni Università di Trieste, 2012, s. 102.

2 SAFJAN, M.: A Union of Effective Judicial Protection: Addressing a multi-level challenge through the lens of Article 47 CFREU. King's College London, 2014, s. 1.

3 Prvú zmienku o súdnej ochrane nachádzame už vo Velkej lisitine slobôd (Magna Charta Libertatum) z roku 1215, podl'a ktorej článku 39 nemohol byt' nijakým spôsobom „slobodný človek“ zatknutý, uväznený, poslaný do vyhnanstva alebo upálený bez zákonného rozsudku. Garanciu čestného súdneho konania sl'uboval aj uhorský král' Ondrej II. Zlatou bulou z roku 1222. 
potrebné všetkým jednotlivcom, ktorým sú priznané práva a slobody poskytnút' garanciu, že tieto práva sú vymožitel'né a existuje právo na ich účinnú súdnu ochranu v prípade, ak dôjde k porušeniu týchto práv. ${ }^{4} \mathrm{Na}$ úrovni Európskej Únie zohral v systéme súdnej ochrany práv jednotlivcov kl’účovú úlohu Súdny dvor EÚ, ktorý v rámci svojej rozhodovacej činnosti objavil všeobecnú právnu zásadu práva na účinnú súdnu ochranu, pričom jeho inšpiračnými prameňmi sa stali spoločné ústavné tradície členských štátov, čl. 6 a čl. 13 Dohovoru o ochrane l'udských práv a základných slobôd (d’alej len ako „Dohovor"). ${ }^{5}$ Obsahom všeobecnej právnej zásady práva na účinnú súdnu ochranu bolo a stále je zabezpečenie prístupu k spravodlivosti. Všeobecná právna zásada práva na účinnú súdnu ochranu objavená v judikatúre Súdneho dvora EÚ sa postupom času stala súčast'ou prameňov sekundárneho práva Únie, ako aj súčast'ou mnohých oblastí politík Únie. ${ }^{6}$ So vstupom Lisabonskej zmluvy do platnosti právo na účinnú súdnu ochranu dostalo svoju výslovnú a kodifikovanú podobu v Charte, ktorá sa stala prameňom primárneho práva. ${ }^{7} \mathrm{~V}$ zmysle judikatúry Súdneho dvora EÚ došlo prijatím čl. 47 Charty k opätovnému potvrdeniu všeobecnej právnej zásady práva na účinnú súdnu ochranu $^{8}$ a k jej výslovnej formulácii ${ }^{9}$. Článok 47 Charty, obsiahnutý v VI. hlave Charty s názvom Spravodlivost' sa stal v únijnom práve hlavným pilierom základného práva na účinnú súdnu ochranu a jeho ochrany.

Základné právo na účinnú súdnu ochranu tak, ako je upravené v Charte, zahŕn̆a celý súbor práv jednotlivca, ktoré majú zabezpečit' efektívnu procesnú ochranu jeho práv a slobôd poskytovaných Úniou. Vychádzajúc z dikcie čl. 47 Charty, každý koho práva alebo slobody zaručené právom Únie boli porušené, má právo na účinný prostriedok nápravy pred súdom a právo na spravodlivý proces. Samotné základné právo na účinnú súdnu ochranu sa skladá z viacerých zložiek, ktoré zahrňujú najmä právo na obranu, zásadu rovnosti zbraní, právo na prístup k súdu, ako aj právo poradit'sa, obhajovat' sa či nechat' sa zastupovat'. ${ }^{10}$ Právo na účinný prostriedok nápravy v sebe zahŕňa aj právo na náhradu škody ak sa zistí, že došlo k porušeniu únijného práva. O naplnení práva na spravodlivé súdne konanie možno hovorit' len vtedy, ak bude jednotlivcom zabezpečené ich právo na prístup $\mathrm{k}$ súdu, pričom súd rozhodujúci v danej veci musí byt' nezávislý a nestranný, musí byt' zriadený zákonom, rozhodnút' v primeranom čase, riadne (re-

${ }^{4}$ PERCINE, I.: The right to Effective Judicial Protection and Remedies in the EU. In: ROSAS, A. - LIVITS, E. - BOTS, Y. (eds.): The Court of Justice and the Construction of Europe: Analyses and Perspectives on Sixty Years of Case-law. The Hague: Asser Press, 2013.

5 Pozri napr. C-222/84 Marguerite Johnston proti Chief Constable of the Royal Ulster Constabulary, ECLI: EU:C:1986:206; C-222/86 Union nationale des entraineurs et cadres techniques proffessionnels du footfall (Unectef) proti George Heylens, Jacques Dewailly, Jacques Amyot a Roger Deschod, ECLI: EU:C:1987:442.

${ }^{6}$ PRECHAL, S.: The Court of Justice and Effective Judicial Protection: What Has the Charter Changed? In: PAULUSSEN, Ch. - TAKÁCS, T. - LAZIĆ, V. - VAN ROMPUY, B. (eds.): Fundamental Rights in International and European Law: Public and Private Law Perspectives. The Hague: T.M.C. ASSER PRESS, 2016, s. 155.

7 Charta základných práv EÚ sa prostredníctvom legislatívneho odkazu v čl. 6 ZEÚ stala súčast’ou primárneho práva Únie, čím získala právnu záväznost'.

8 Spojené veci C-317/08 až C-320/08 Rosalba Alassini proti Telecom Italia SpA a Filomena Califano proti Wind SpA a Lucia Anna Giorgia Iacono proti Telecom Italia SpA a Multiservice Srl proti Telecom Italia SpA, ECLI:EU:C:2010:146.

9 C-199/11 Europese Gemeenschap proti Otis NV a i., ECLI:EU:C:2012:684.

10 C-199/11 Europese Gemeenschap proti Otis NV a i., ECLI:EU:C:2012:684. 
levantne) odôvodnit' svoje rozhodnutie. Medzi d’alšie procesné zložky účinnej súdnej ochrany je možné nepochybne zahrnút' okrem zásady rovnosti zbraní, aj zásadu procesnej rovnosti strán $\mathrm{v}$ konaní ${ }^{11}$ a zásadu kontradiktórnosti konania, ktorá predstavuje súčast' práva na obranu. ${ }^{12}$

Textácia čl. 47 Charty sa vo vel'kej miere zhoduje so znením čl. 6 a čl. 13 Dohovoru, ked’že práve uvedené články Dohovoru boli jedným z hlavných inšpiračných prameňov pri tvorbe Charty. Komparáciou textu Charty s textom Dohovoru možno dospiet' k záveru, že čl. 47 Charty má širší rozsah uplatňovania, nakol'ko sa uplatňuje pri rozhodovaní o všetkých právach a slobodách zaručených právom Únie, narozdiel od čl. 6 ods. 1 Dohovoru, ktorý sa uplatňuje len pri rozhodovaní o občianskych právach a záväzkoch alebo o trestných činoch. Pri rozhodovaní o aplikácií čl. 6 Dohovoru je preto potrebné skúmat', či daná vec podlieha pod občianske práva a záväzky alebo ide o trestný čin, zatial' čo pri aplikácií čl. 47 Charty je potrebné skúmat' len to, či ide o právo alebo záväzok vyplývajúci z práva Únie. Ochranu porušených práv alebo záväzkov jednotlivcov zabezpečujú podl'a čl. 47 Charty súdy, ktoré disponujú právomocou rozhodovat' o jeho právach a záväzkoch vyplývajúcich z Charty, konkrétne ide o všetky vnútroštátne súdne orgány a Súdny dvor EÚ. Narozdiel od Charty, čl. 6 Dohovoru priznáva jednotlivcovi právo na účinný prostriedok nápravy pred vnútroštátnym orgánom, medzi ktoré nepochybne patrí aj vnútroštátny súd.

Adresátom základného práva vyplývajúceho z čl. 47 Charty je každý jednotlivec, ktorého práva alebo slobody zaručené právom Únie boli porušené. Aplikácia čl. 47 Charty sa nevzt’ahuje len na porušenia základných práv alebo slobôd vyplývajúcich z Charty, ale aplikuje sa pri porušení akýchkol'vek práv alebo slobôd vyplývajúcich jednotlivcom z práva Únie. Ciel'om čl. 47 Charty je poskytnutie ochrany všetkým právam a slobodám, ktoré jednotlivcom zaručuje právo Únie, avšak neposkytuje ochranu právam a slobodám, ktoré vyplývajú jednotlivcom z čisto vnútroštátnych právnym predpisov. Článok 47 Charty, ktorý upravuje základné právo na účinnú súdnu ochranu určuje okruh povinných subjektov, ktoré majú túto ochranu zabezpečit'. Týmito subjektami stanovenými Chartou sú práve a len súdy, konkrétne Súdny dvor EÚ a vnútroštátne súdy členských štátov. Základné právo na účinnú súdnu ochranu zakotvené v čl. 47 Charty vyžaduje, aby súdy zaistili účinnú súdnu ochranu všetkých únijných práv, čo znamená, že adresáti tohto základného práva musia mat' možnost' podrobit' súdnemu preskúmaniu v zásade každý zásah do svojich únijných práv. Povinnost' uskutočňovat' súdne preskúmanie sa vzt’ahuje tak na vnútroštátne súdy poverené aplikáciou práva Únie, ako aj na Súdny dvor EÚ v rámci jeho právomocí.

Na to, aby vnútroštátne súdy členských štátov mohli rozhodovat' o porušenom práve Únie a poskytnút' mu súdnu ochranu zaručenú jednotlivcom Chartou, je ich úplne prvou úlohou zistit', či je možné na daný prípad Chartu aplikovat'. V zmysle čl. 51 ods. 1 sú ustanovenia Charty pri dodržaní zásady subsidiarity určené pre inštitúcie, orgány, úrady a agentúry Únie, a tiež pre členské štáty výlučne vtedy, ak vykonávajú právo Únie. Otázka osobnej pôsobnosti Charty v praxi nevyvoláva žiadne väčšie problémy, avšak

11 C-205/15 Directia Generala a Finantelor Publice Brasov proti Vasilemu Tomovi, Biroul Executorului Judecatores Horatiu-Vasile Cruduleci, ECLI:EU:C:2016:499.

12 C-437/13 Unitrading Ltd proti Staatsecretais van Financien, ECLI:EU:C: 2014:2318. 
problematickou sa stala otázka vecnej pôsobnosti Charty, ktorá je obmedzená vo vzt'ahu k členským štátom Únie tým spôsobom, že Charta je pre nich záväzná výlučne len vtedy, ak vykonávajú právo Únie. ${ }^{13}$ Práve formulácia obmedzenej vecnej pôsobnosti - ak vykonávajú právo Únie, otvorila debatu o tom, ako je potrebné uvedený pojem vykladat'. Súdny dvor uviedol, že medzi pojmami vykonávanie práva Únie a konanie v rámci pôsobnosti práva Únie, nie je potrebné robit žiaden rozdiel. ${ }^{14}$ Samotný pojem vykonávanie práva Únie predpokladá existenciu súvisu medzi aktom práva Únie a dotknutým vnutroštátnym opatrením, teda v konkrétnej situácií musí existovat' dostatočné prepojenie na právo Únie, aby sa ustanovenia Charty na túto situáciu mohli aplikovat'. Základné práva a slobody uvedené v Charte nie sú spôsobilé na samostatnú aplikáciu, a preto je nevyhnutné, aby sa pri ich aplikácií použilo aspoň jedno iné právne pravidlo práva Únie, ktoré sa musí v konkrétnej veci reálne uplatňovat' a nielen interpretovat'. Reálne uplatnenie tohto iného pravidla práva Únie sa musí prejavovat' v konkrétnej a objektívne určitel'nej spojitosti s vecou samou. ${ }^{15}$ Nemožno však zabúdat' na to, že podl'a čl. 51 ods. 2 Charty, Charta nijakým spôsobom nerozširuje rozsah pôsobnosti práva Únie nad rámec právomocí Únie, ani nezakladá žiadnu novú právomoc ani úlohu pre Úniu, ani nemení právomoci a úlohy vymedzené v zmluvách. V čl. 51 ods. 2 Charty obsahuje výslovné vyjadrenie toho, čo logicky vyplýva zo zásady subsidiarity a zo skutočnosti, že Únia disponuje výlučne len právomocami, ktoré boli na ňu prenesená členskými štátmi v zmluvách. ${ }^{16}$

Pre aplikáciu článku 47 Charty uvedené znamená, že procesné záruky a postupy uvedené v tomto článku sa nadobúdajú vo vzt’ahu k svojmu adresátovi právne účinky len vtedy, ak existuje prepojenie na iné ustanovenie práva Únie, ktoré je aplikovatel'né. Ak sa teda jednotlivec chce domáhat' účinnej súdnej ochrany, ktorá mu je priznaná čl. 47 Charty, musí mu byt' jeho porušené právo, ochrany ktorého sa domáha, priznané právom Únie a nie vnútroštátnym právom.

\section{SÚDNY DVOR EÚ AKO GARANT ZÁKLADNÉHO PRÁVA JEDNOTLIVCA NA ÚČINNÚ SÚDNU OCHRANU V PREJUDICIÁLNOM KONANÍ}

Spoločnou úlohou súdov Únie, skladajúcich sa z úniových a vnútroštátnych súdov je zabezpečit’ na celom území Únie uplatňovanie a dodržiavanie práva Únie. Vzt’ah týchto súdov nie je klasickým hierarchickým vzt’ahom, ale je vzt’ahom založeným na princípoch spolupráce, decentralizácie a subsidiarity. Základné právo na účinnú súdnu ochranu zakotvené v čl. 47 Charty si vyžaduje, aby vnútroštátne súdy členských

13 SARMIENTO, D.: Who's afraid of the Charter? The Court of Justice, national courts and the new framework of fundamental rights protection in Europe. Common Market Law Review, 2013, č. 5, s. 1273.

14 Napr. C-617/10 Aklagaren proti Hans Åkerberg Fransson, ECLI:EU:C:2013:105; C-265/13 Emiliano Torralbo Marcos proti Korota SA a Fondo de Garantía Salarials, ECLI:EU:C:2014:187; C-198/13 Victor Manuel Julian Hernández a i. proti Reino de España (Subdelegación del Gobierno de España en Alicante) a i., ECLI:EU:C:2014:2055.

15 MAZÁK, J. - JÁNOŠÍKOVÁ, M. a kol.: Charta základných práv Európskej únie v konaniach pred orgánmi súdnej ochrany v Slovenskej republike. Košice: EQUILIBRIA, 2016, s. 33.

16 Tamtiež, s. 51. 
štátov a Súdny dvor EÚ zaistili účinnú súdnu ochranu porušených únijných práv jednotlivcov. ${ }^{17}$ Základnou úlohou Súdneho dvora EÚ je zabezpečovat' dodržiavanie práva pri výklade a uplatňovaní zmlúv, ${ }^{18}$ pričom je jedinou inštitúciou Únie, ktorej je zverená právomoc vykladat' právo Únie, a to ako právo primárne, tak aj právo sekundárne. Prirovnaním Súdneho dvora k vnútroštátnym súdnym sústavám je možné konštatovat', že Súdny dvor plní úlohy ústavného súdu ${ }^{19}$, najvyššieho správneho súdu ${ }^{20}$, ako aj medzinárodného súdu. ${ }^{21}$ Zatial' čo Súdny dvor EÚ objavuje a určuje princípy a zásady, ktoré musia byt' dodržané na zabezpečenie účinnej súdnej ochrany práv jednotlivcov, je úlohou členských štátov zabezpečit systém vnútroštátnych prostriedkov nápravy, ktorý bude pre jednotlivcov prístupný a účinný, čím zabezpečia jeho prístup k účinnému konania pred vnútroštátnym súdom stanovenej kvality. ${ }^{22}$

Z hl'adiska uplatňovania základného práva na účinnú súdnu ochranu sú pre jednotlivca na úrovni Únie významné najmä dva typy konania - konanie o prejudiciálnej otázke (tzv. prejudiciálne konanie) a konanie o neplatnost' aktu podla čl. 263 Zmluvy o fungovaní Európskej únie (d’alej len ako „ZFEÚ“), ktoré sa navzájom výrazne líšia z hl’adiska účelu a výsledku, ktorý sa má dosiahnút'. Kým prostredníctvom nesporového prejudiciálneho konania Súdny dvor EÚ zabezpečuje výklad práva Únie, v rámci sporového konania o neplatnost' aktu Súdny dvor EÚ rozhoduje o platnosti aktu inštitúcie Únie, ktorý mohol zasiahnút' do práv jednotlivcov. Premietnutím na problematiku čl. 47 Charty to znamená, že v prejudiciálnom konaní Súdny dvor vykladá obsah a rozsah základného práva jednotlivca na účinnú súdnu ochranu, podmienky jeho aplikovatel'nosti, ale i rozsah jeho obmedzenia; na druhej strane v rámci konania o neplatnost' aktu Všeobecný súd v prvom stupni a následne v odvolacom konaní Súdny dvor rozhodujú priamo o porušení konkrétnych únijných práv jednotlivcov, čím dochádza k uplatneniu základného práva jednotlivca na účinnú súdnu ochranu.

Prejudiciálne konanie predstavuje typ konania, ktorý zabezpečuje nevyhnutné spojítko medzi vnútroštátnym právnym systémom a právnym systémom Únie a vytvára skutočný dialóg medzi vnútroštátnym sudcom a sudcom Únie. Výkladom jednotlivých ustanovení práva Únie Súdny dvor určuje, spresňuje a objasňuje ich význam, obsah alebo rozsah, čo má v konečnom dôsledku najväčší vplyv práve na jednotlivcov, nakol'ko vnútroštátny súdny orgán je viazaný autoritatívnym výkladom práva Únie uskutočneným Súdnym dvorom. Súdny dvor sa v rámci konania o prejudiciálnej otázke mnohokrát venoval aj výkladu základného práva na účinnú súdnu ochranu, pričom venoval

17 SAFJAN, M. A.: Union of Effective Judicial Protection: Addressing a multi-level challenge through the lens of Article 47 CFREU. King's College London, 2014, s. 1.

18 Čl. 19 ods. 1 ZEÚ.

19 Ako ústavný súd je Súdny dvor strážcom ciel'ov a hodnôt stanovených v zakladajúcich zmluvách, z čoho vyplýva, že zabezpečuje aj ochranu základným právam a slobodám zakotvených v Charte a zároveň zabezpečuje zjednocovanie aplikácie a interpretácie únijného práva rozhodovaním o prejudiciálnych otázkach.

20 V postavení najvyššieho správneho súdu poskytuje Súdny dvor ochranu subjektívnym právam jednotlivcov pred protiprávnymi aktmi únijných inštitúcií.

21 SYllovÁ, J. - PíTROVÁ, L. - PALDUSOVÁ, H. a kol.: Lisabonská smlouva. Komentář. Praha: C.H. Beck, 2010, s. 110.

22 RAVO, L. M.: The role of the Prinicple of Effective Judicial Protection in the EU and its Impact on National Jurisdictions. In: Sources of Law and Legal Protection, (Triestine Lecture; 1), EUT Edizioni Università di Trieste, 2012, s. 107. 
pozornost' najmä základným právam, ktoré tvoria jeho integrálne zložky, čím postupne dotváral a rozvíjal jeho samotný obsah.

V prejudiciálnom konaní vo veci Alpha Bank Cyprus Ltd ${ }^{23}$ týkajúceho sa výkladu nariadenia o doručovaní písomnosti, ${ }^{24}$ ktorého ciel'om je zlepšit' efektívnost' a rýchlost' súdnych konaní a zabezpečit' riadny výkon spravodlivosti zavedením zásady priameho odosielanie súdnych a mimosúdnych písomnosti medzi členskými štátmi, Súdny dvor uviedol, že tieto ciele nie je možné dosiahnut' tak, že sa akýmkol'vek spôsobom oslabí právo adresátov písomnosti na obranu, ktoré je odvodené od základného práva na spravodlivý proces. Ak má byt' právo na obranu plne zabezpečené adresátovi písomnosti, je potrebné dbat' na to, aby adresát skutočne predmetnú písomnost' prevzal, ale aj na to, aby mal možnost' spoznat, účinne a úplne pochopit’ význam a dosah návrhu, ktorý bol proti nemu podaný v cudzine, tak, aby mohol účinne a čo najlepšie uplatnit' svoje práva v členskom štáte pôvodu. Je potrebné, aby sa pri doručovaní písomnosti adresátovi zabezpečila primeraná ochrana jeho práva na obranu, ktorá zabezpečí ochranu jeho základného práva zaručeného čl. 47 Charty.

$\mathrm{K}$ podobným záverom týkajúcim sa práva na účinný prostriedok nápravy garantovaného čl. 47 Charty dochádza Súdny dvor aj v prejudiciálnom konaní vo veci Eamonn Donnellan ${ }^{25}$, týkajúceho sa výkladu smernice o vzájomnej pomoci pri vymáhani pohl'adávok vyplývajúcich z daní, poplatkov a d’alších opatrení. ${ }^{26}$ Podstata prejudiciálnej otázky spočívala v tom, či je možné aby dožiadaný orgán členského štátu odmietol vykonat' žiadost' o vymáhanie pohl'adávky súvisiacej s finančou sankciou uloženou v dožadovanom členskom štáte z dôvodov spojených s právom dotknutej osoby na účinný prostriedok nápravy na súde. Súdny dvor najskôr v rozsudku pripomenul zásadný význam zásady vzájomnej dôvery medzi členskými štátmi, ktorá umožňuje vytváranie a zachovanie priestoru bez vnútorných hraníc, následne však uviedol, že je možné jej obmedzenie za vel'mi striktných podmienok, akou je napríklad rozpor s verejným poriadkom. V dožiadanom členskom štáte, sa za rozpor s verejným poriadkom považuje aj neoznámenie finančnej sankcie dotknutej osobe a dôvody týkajúce sa porušenia práva na účinný prostriedok nápravy pred súdom. Súdny dvor v tomto rozsudku uviedol, že na to, aby mohla dotknutá osoba efektívne vykonávat' svoje právo na účinný prostriedok nápravy garantované čl. 47 Charty proti rozhodnutiu, ktorého je adresátom a ktoré jej spôsobuje ujmu, musí poznat' dôvody, na ktorých je toto rozhodnutie založené. Oboznámit' dotknutú osobu s dôvodmi je možné bud' prečítaním samotného rozhodnutia, alebo oznámením týchto dôvodov na žiadost' dotknutej osoby, tak aby mohla bránit' svoje práva za čo najlepších podmienok. Na to, aby bolo možné zabezpečit' dodržanie práv garantovaných čl. 47 Charty je potrebné dbat' nielen na to, aby bol adresátovi naozaj predmetný akt doručený, ale aj na to, aby sa bol schopný oboznámit' sa a porozumiet' účinne a úplne významu a dosahu tohto aktu vydaného v zahraničí, a mohol účinne

23 C-519/13 Alpha Bank Cyprus Ltd proti Dau Si Senh a i., ECLI:EU:C:2015:603.

24 Nariadenie Európskeho parlamentu a Rady (ES) č. 1393/2007 z 13. novembra 2007 o doručovaní súdnych a mimosúdnych písomností v občianskych a obchodných veciach v členských štátoch a o zrušení nariadenia Rady (ES) č. 1348/2000, Ú. v. EÚ L 324, 10.12.2007, s. 79-120.

25 C-34/17 Eamonn Donnellan proti The Revenue Commissioners, ECLI:EU:C:2018:282.

26 Smernica Rady 2010/24/EÚ zo 16 marca 2010 o vzájomnje pomoci pri vymáhaní pohl'adávok vyplývajúcich z daní, poplatkov a d'alších opatrení, Ú. v. EÚ L 84, 31.3.2010, s. 1-12. 
uplatnit' svoje práva $\mathrm{v}$ členskom štáte pôvodu, teda aby sa rozhodol či je potrebné sa obrátit’ na súd v členskom štáte pôvodu. V predmetnej veci nebolo rozhodnutie, na základe ktorého dožadujúci orgán vymáha pohl’adávku, riadne oznámené dotknutej osobe, predtým ako bola žiadost' o vymáhanie pohl'adávky podaná na dožiadaný orgán, v dôsledku čoho došlo k porušeniu jej základného práva na účinu súdnu ochranu, ked’že dotknutá osoba nebola schopná využit účinný prostriedok nápravy proti rozhodnutiu ukladajúcemu jej finančnú sankciu v danom členskom štáte.

Procesnými zárukami účinnej súdnej ochrany sa Súdny dvor zaoberal aj v prejudiciálnom konaní týkajúcom sa výkladu smernice o administratívnej spolupráci v oblastí daní, ${ }^{27}$ ako aj článku 47 Charty v správnom konaní vo veci Berlioz Investment Fund $S A .{ }^{28}$ Súdny dvor vo vzt’ahu k možnosti uplatnenia čl. 47 Charty, najmä právu na účinný prostriedok nápravy v správnom konaní uvádza, že sa ho môže dovolávat' každý účastník správneho konania, proti aktu, ktorý mu spôsobuje ujmu, akou je napríklad uloženie sankcie alebo sankčné opatrenie. Súdny dvor vychádzajúc z dikcie čl. 47 Charty uvádza, že každý má právo na to, aby jeho záležitost' bola prejednaná nezávislým a nestranným súdom, pričom dodržanie tohto práva predpokladá, že rozhodnutie správneho orgánu, ktoré samo osebe nespíňa podmienky nezávislosti a nestrannosti, podlieha následnemu preskúmaniu súdnym orgánom. Preto aj účastník správneho konania, ktorý nesplnil povinnost' uloženú správnym rozhodnutím, za nesplnenie ktorej mu bolo uložené finančné opatrenie, musí mat' priznanú a reálnu možnost' súdneho preskúmania zákonnosti sankčného opatrenia správneho orgánu, tak aby mu bolo v plnej miere zabezpečená účinná súdna ochrana jeho práv. Samotné súdne preskúmanie zaručené čl. 47 Charty má byt' účinné, pričom sa v ňom má uplatňovat' zásada rovnosti zbraní, ktorá je logickým dôsledkom samotného pojmu spravodlivý proces.

Prostredníctvom rozmanitých prejudiciálnych otázok členských štátov sa Súdnemu dvoru naskytá možnost' nad’alej objasňovat' a spresňovat' obsah základného práva na účinnú súdnu ochranu. Práve prostredníctvom rozhodovacej činnosti Súdny dvor vytvára limity uplatňovania a ochrany základného práva na účinnú súdnu ochranu dochádza $\mathrm{k}$ vytvorenie kvalitného a účinného systému súdnej ochrany.

\section{SÚDNY DVOR EÚ AKO GARANT ZÁKLADNÉHO PRÁVA JEDNOTLIVCA NA ÚČINNÚ SÚDNU OCHRANU V KONANÍM O NEPLATNOSŤ AKTU}

Systém súdnej ochrany na úrovni Únie a pred Súdnym dvorom EÚ by nemohol byt' úplný, ak by neexistovala možnost' jednotlivcov podat' žalobu proti aktom inštitúcií Únie, čo má zabezpečit' preskúmanie zákonnosti týchto aktov. ${ }^{29}$ Konanie o neplatnost' aktu predstavuje najvýznamnejšie konanie pre jednotlivcov na úrovni Únie,

27 Smernica Rady 2011/16/EÚ z 15. februára 2011 o administratívnej spolupráci v oblasti daní a zrušení smernice 77/799/EHS, Ú. v. EÚ L 64, 11.3.2011, s. 1-12.

28 C-682/15 Berlioz Investment Fund SA proti Directeur de ládministration des contributions directes, ECLI: EU:C:2017:373.

29 LENAERTS, K. The rule of Law and the coherence of the judicial system of the European Union. Common Market Law Review, 2007, č. 6, s. 1626. 
nakol'ko zabezpečuje súdnu kontrolu činností inštitúcií Únie, ako aj súdnu ochranu jich práv. Jednotlivec (fyzická alebo právnická osoba) môže za podmienok ustanovených v článku 263 ZFEÚ podat' žalobu proti aktom, ktoré sú mu určené alebo ktoré sa ho priamo a osobne týkajú, ako aj voči regulačným aktom, ktoré sa ho priamo týkajú a nevyžadujú vykonávacie opatrenia. ${ }^{30}$ Žaloba o neplatnost' predstavuje jedinú priamu formu, ktorou môžu jednotlivci ako neprivilegovaní žalobcovia, žiadat’ súdne preskúmanie platnosti úniového práva. Príslušným na konanie je $\mathrm{v}$ prípade žalôb jednotlivcov proti aktom inšitúcií Únie podl'a čl. 263 ods. 4 ZFEÚ Všeobecný súd. Podmienky prípustnosti žaloby neprivilegovaných žalobcov sú stanovené v troch okruhoch:

1. V prvom prípade môže jednotlivec podat' žalobu o neplatnost' aktov, ktorých je ako žalobca adresátom. Pri tejto skupine aktov je na podanie žaloby jednotlivcom postačujúce to, že je v právnom akte Únie stanovený ako osoba, ktorej je tento akt určený.

2. V druhom prípade môže jednotlivec podat žalobu o neplatnost' aktov určených iným osobám, ktoré sa ho priamo a osobne týkajú. Žalobca v prípade tejto skupiny aktov musí preukazovat' kumulatívne splnenie dvoch podmienok - svoju priamu dotknutost ${ }^{31}$ a osobnú dotknutost'. ${ }^{32}$ Uvedené podmienky musia byt' splnené kumulatívne, čo sa vo vel'kom množstve prípadov ukazuje ako t’ažko splnitel'né, najmä kvôli podmienke osobnej dotknutosti a je chápané ako obmedzenie prístupu jednotlivca $\mathrm{k}$ súdu, čo $\mathrm{v}$ konečnom dôsledku znamená obmedzenie jeho základného práva na účinnú súdnu ochranu.

3. V tret'om prípade môže jednotlivec svojou žalobou o neplatnost' aktu napadnút' - regulačné akty, ktoré sa ho priamo týkajú a nevyžadujú vykonávacie opatrenia., t.j. sú samovykonatel'né. V porovnaní s druhou skupinou aktov, ktoré môže jednotlivec napadnút', došlo k odstráneniu pomerne náročnej podmienky - podmienky osobnej dotknutosti. Skupina regulačných aktov bola zavedená až Lisabonskou zmluvou, ako reakcia na vel'mi obmedzené možnosti jednotlivca podat' žalobu proti aktom Únie, čo bolo možné chápat' ako obmedzenie jeho základného práva na účinnú súdnu ochranu. ${ }^{33}$ Problém obmedzenia prístupu jednotlivcov na súd sa však defi-

30 Článok 263 ods. 4 ZFEÚ.

31 Podmienka priamej dotknutosti vyžaduje, aby mal predmetný akt priame účinky na právne postavenie jednotlivca a neponechával jeho adresátom, ktorí sú poverení jeho vykonaním žiadnu vol’nost' uváženia, tak aby toto vykonanie aktu bolo automatickej povahy a vyplývalo výlučne z predmetnej právnej úpravy, bez potreby prijatia d’alších vykonávacích opatrení. Bližšie pozri: TOMÁŠEK, M. - TÝČ , V. a kol.: Právo Evropské unie. Praha: Leges, 2013, s. 424.

32 Osobná dotknutost' žalobcu sa posudzuje na základe tzv. Plaumanovho testu, podl’a ktorého subjekty iné ako osoby, ktorým je rozhodnutie určené môžu tvrdit', že sa ich rozhodnutie osobne týka iba vtedy, ked' sa ich dotýka na základe ich určitých osobitných vlastností alebo na základe faktickej situácie, ktorá ich vymedzuje vo vzt’ahu k akejkol'vek inej osobe, a tým ich individualizuje obdobným spôsobom ako osobu, ktorej je rozhodnutie určené.

$33 \mathrm{~V}$ predlisabonskom období mohol jednotlivec podat žalobu len v dvoch uvedených prípadoch, t.j. proti aktom, ktoré sú mu určené alebo proti aktom, ktoré sa ho priamo a osobne týkajú. Práve nesplnenie podmienky osobnej dotknutosti znamenalo zamietnutie žaloby ako neprípustnej, čím sa zabránilo v priamom prístupe jednotlivca k súdom Únie proti aktom všeobecnej platnosti. Príliš obmedzujúcej podmienky osobnej dotknutosti, v snahe zabezpečit' efektívny prístup jednotlivcov na súdy Únie sa venoval vo svojej rozhodovacej činnosti aj Súdny dvor EÚ, ktorý uviedol, že je potrebné podmienku osobnej dotknutosti vykladat' v súvislosti so zásadou účinnej súdnej ochrany, berúc do úvahy rôzne okolnosti, ktoré sú schopné individualizovat'žalobcu. Takýto výklad však nemôže viest' k vylúčeniu tejto podmienky osobnej dotknutosti žalobcu, nakol'ko ide o podmienku výslovne uvedenú v primárnom práve (Rozsudok Súdneho 
nitívne nevyriešil, kým nebolo zrejmé, aký je obsah pojmu regulačný akt, ked’že ide o pojem, ktorý je $\mathrm{v}$ zmluve použitý len na jednom mieste, a to práve $\mathrm{v}$ čl. 263 ods. 4 ZFEÚ. Konečné slovo pri vyjasnení jeho obsahu mal Súdny dvor EÚ, ktorý stanovil, že pojem regulačný akt sa má chápat' tak, že sa týka akéhokol'vek aktu so všeobecnou pôsobnost'ou s výnimkou legislatívnych aktov. Legislatívny akt preto môže byt' predmetom žaloby o neplatnost' podanej fyzickou alebo právnickou osobou, ak sa jej priamo a osobne týka. ${ }^{34}$ Napriek snahe posilnit' aktívnu legitimáciu jednotlivca v konaní o neplatnost' aktu, nebola ani pri Lisabonskej zmluve ochota členských štátov zmenit' toto konanie na konanie o ústavnú st’ažnost' so širokou aktívnou legitimáciou jednotlivca. Nad’alej dochádza $\mathrm{k}$ ponechaniu reštriktívneho prístupu, pokial' ide o žaloby jednotlivcom proti legislatívnym aktom. Účelom tretej vety čl. 263 ods. 4 ZFEÚ je umožnit' fyzickej alebo právnickej osobe podat' žalobu proti aktom so všeobecnou pôsobnost'ou, ktoré nie sú legislatívnymi aktmi, priamo sa jej týkajú a nevyžadujú vykonávacie opatrenia. Práve nová skupina regulačných aktov, ktorú prieniesla Lisabonská zmluva v značnej miere posilnila súdnu ochranu práv jednotlivcov proti aktom Únie, čím posilnila postavenie jednotlivcov na úrovni Únie a rešpektovanie im priznaného základného práva na účinnú súdnu ochranu. ${ }^{35}$

Samotná podstata konania o neplatnost', ako už bolo uvedené, spočíva v možnosti jednotlivca podat' na súd žalobu za účelom ochrany svojich práv, ako aj za účelom kontroly činnosti jednotlivých inštitúcií Únie. Práve iniciovaním konania o neplatnost' proti aktu Únie, jednotlivec realizuje jemu priznané právo na účinnú súdnu ochranu, ktorého plné uplatnenie a ochranu je mu v tomto prípade povinný poskytnút' Všeobecný súd. Súdny dvor spolu so Všeobecným súdom plnia pri zabezpečovaní efektívnej súdnej ochrany práv jednotlivcov nenahraditel'nú úlohu, na jednej strane výkladom ustanovení upravujúcich základné právo jednotlivca na účinnú súdnu ochranu a jednak rozhodovaním o priamych žalobách jednotlivcov.

\section{VNÚTROŠTÁTNE SÚDY ČLENSKÝCH ŠTÁTOV A ZÁKLADNÉ PRÁVO JEDNOTLIVCA NA ÚČINNÚ SÚDNU OCHRANU}

Vel'mi dôležitou súčast’ou súdneho systému Únie sú vnútroštátne súdne orgány, ktoré okrem rozhodovania o ochrane práv vyplývajúcich z vnútroštátneho práv-

dvora C-50/00 P Unión de Pequeños Agricultores proti Rade Európskej únie, ECLI:EU:C:2002:462; C-263/02 P Komisia Európskych spoločenstiev proti Jégo-Quéré \& Cie SA, ECLI:EU:C:2004:210).

Súdny dvor v oboch rozsudkoch uznal význam práva na účinnú súdnu ochranu, avšak konštatoval, že nedochádza $\mathrm{k}$ jeho porušeniu, ked’že žaloba o neplatnost' nie je jediným právnym prostriedkom na ochranu práv jednotlicov, nakol'ko jednotlivec môže využit' aj iné právne prostriedky na ochranu svojich práv, ktoré sú mu v súlade s princípom lojality členské štáty povinné umožnit' využit'. Bolo zrejmé, že výkladom primárneho práva Únie sa náročná podmienka osobnej dotknutosti nepreklenie a zmena sa môžno dosiahnút' len zmenou textu zakladajúcich zmlúv, ktorý priniesla práve Lisabonská zmluva zavedením tejto tretej kategórie aktov, ktoré môže jednotlivec napadnút žalobou o neplatnost'.

34 T-18/10 Inuit Tapiriit Kanatami a i. proti Európskemu parlamentu a Rade Európskej únie, ECLI: EU:T:2011:419.

35 ALBORS-LLORENS, A.: Judicial protection before the Court of Justice of the European Union. In: BARNARD, C. - PEERS, S.: European Union Law. Oxford: Oxford University Press, 2017, s. 276-277. 
neho poriadku, v prvej línií rozhodujú aj o ochrane porušených práv jednotlivcov vyplývajúcich z práva Únie. Základné právo na účinnú súdnu ochranu a jeho uplatňovanie boli už od počiatku svojej existencie v značnej miere ovplyvňované decentralizovaným systémom právnych prostriedkov nápravy a zabezpečením prístupu $\mathrm{k}$ súdu, ktoré boli založené na vzájomnom vzt’ahu Súdneho dvora EÚ a vnútroštátnych súdnych orgánov. Vnútroštátne súdne orgány by vo veciach ochrany únijných práv jednotlivcov nemohli rozhodovat', pokial' by neexistovali princíp priameho účinku práva Únie ${ }^{36}$ a princíp prednosti práva Únie pred vnútroštátnym právom. ${ }^{37}$ Práve existencia princípov prednosti a priameho účinku prispela $\mathrm{v} 70$ rokoch $\mathrm{k}$ otvoreniu a následnému zodpovedaniu otázok týkajúcich sa právnej úpravy národných procesných pravidiel a účinných prostriedkov nápravy poskytovaných vnútroštátnymi súdnymi orgánmi. Východiskovým bodom bolo vytvorenie a pomenovanie princípu, ktorý dnes poznáme ako princíp procesnej autonómie

Za účelom zabezpečenia účinnej ochrany svojich porušených práv vyplývajúcich z práva Únie sa jednotlivec môže obrátit’ na vnútroštátny súd konkrétneho členského štátu, ktorého povinnost'ou je poskytnút' jednotlivcom a jeho únijným právam túto účinnú súdnu ochranu. Povinnost' vnútroštátnych súdov členských štátov poskytnút' jednotlivcom súdnu ochranu ich porušených práv vyplývajúcich z práva Únie vyplýva z čl. 47 Charty, ktorý je základným pilierom účinnej súdnej ochrany v práve Únie, a z článku 19 ods. 1 druhého pododseku ZEÚ, ktorý členským štátom stanovuje povinnost' ustanovit' v oblastiach, na ktoré sa vzt'ahuje právo Únie, prostriedky nápravy potrebné na zabezpečenie účinnej právnej ochrany. Výslovná formulácia povinnosti členských štátov zabezpečit' efektívne procesnoprávne predpoklady a podmienky ochrany únijných práv mala prispiet' $\mathrm{k}$ ochrane subjektívných únijných práv jednotlivca $\mathrm{v}$ rámci systému súdnej ochrany Únie. ${ }^{38}$ Situácia, kedy by bolo stanovenie procesných podmienok ponechané výlučne len na členské štáty, by mohla viest’ k tomu, že prístup k súdnej ochrane $\mathrm{v}$ jednotlivých členských štátoch bude značne rozdielny a bude spôsobovat’ nejednotnost' aplikácie práva Únie, čoho následkom by mohlo nastat', že nebude zabezpečená reálna vymožitel'nost' únijného práva. Na túto situáciu reagovalo únijné právo, ktoré podrobilo stanovenie procesného rámca sérií podmienok, ktoré majú za úlohu zabezpečit' reálnu vymožitel'nost' práva Únie pred súdnymi orgánmi členských štátov. Prvá z týchto podmienok stanovuje, že ak únijný zákonodarca prijal samostatnú procesnoprávnu úpravu alebo procesný rámec vyplýva z judikatúry Súdneho dvora, sú členské štáty a ich vnútroštátne súdne orgány povinné z tejto úpravy vychádzat'. ${ }^{39}$

36 Tento princíp Súdny dvor formuloval v rozsudku C-26/62 NV Algemene Transport-en Expeditie Onderneming van Gend \& Loos proti Nederlandse administratie der belastinge, ECLI:EU:C:1963:1.

37 Tento princíp Súdny dvor formuloval v rozsudku C-6/64 Flaminio Costa proti E.N.E.L., ECLI:EU: C:1964:66.

38 SYLLOVÁ, J. - PÍTROVÁ, L. - PALDUSOVÁ, H. a kol.: Lisabonská smlouva. Komentár̆. Praha: C.H. Beck, 2010, s. 112.

39 Pozri napr. rozsudok C-106/77 Administrazione delle finanze dello Stato proti S.p.A. Simmenthal, ECLI:EU:C:1978:49, v ktorom Súdny dvor konštatoval, že vnútroštátny súd je povinný zabezpečit ochranu práv, ktoré mu priznávajú ustanovenia právneho poriadku Únie, bez toho, aby musel žiadat alebo čakat' na skutočné zrušenie oprávnenými vnútroštátnymi orgánmi prípadných vnútroštátnych opatrení, ktoré sú prekážkou priamej a okamžitej aplikácie predpisov Únie, pričom nedochádza k zrušeniu rozpornej vnútroštátnej právnej normy, ale k jej neaplikovatelnosti. 
Druhá podmienka reaguje na situácie, kedy na úrovni Únie neexistuje procesnoprávna úprava. $\mathrm{V}$ týchto situáciach je členský štát povinný prijat' vlastnú procesnoprávnu úpravu v súlade s princípom národnej procesnej autonómie. ${ }^{40}$

Podstata princípu národnej procesnej autonómie spočíva $\mathrm{v}$ tom, že $\mathrm{v}$ prípade absencie právnej úpravy na úrovni Únie, prináleží vnútroštátnym právnym poriadkom všetkých členských štátov určit' príslušné vnútroštátne súdy, systém opravných prostriedkov a postupov zabezpečujúcich účinné súdne preskúmanie práv jednotlivcov, ktoré im vyplývajú z právnych predpisov Únie, ktoré majú priamy účinok; ${ }^{41}$ pričom tieto podmienky nesmú byt' menej priaznivé ako tie, ktoré sa sa týkajú podobných žalôb, ktoré majú svoj základ vo vnútroštátnom práve. $Z$ takto koncipovaného princípu procesnej autonómie vyplývajú dve zásady pre jeho uplatnenie. ${ }^{42}$ Prvá je označovaná ako zásada ekvivalencie (tzv. zásada nediskriminácie), podla ktorej procesné pravidlá upravujúce žaloby na ochranu práv jednotlivcov vyplývajúcich z práva Únie, nesmú byt' menej priaznivé ako tie, ktoré upravujú podobné žaloby vnútroštátnej povahy. Druhou zásadou je zásada efektivity ( $t z v$. zásada praktickej uplatnitel’nosti), ktorá stanovuje, že procesné podmienky vytvorené vnútroštátnym právom nesmú spôsobovat', aby bol výkon práv vyplývajúcich z práva Únie prakticky nemožný alebo vel'mi st’ažený. 43 Povinnost'ou členských štátov je teda v zmysle uvedeného zabezpečovat' ochranu práv jednotlivcov vyplývajúcich z práva Únie tak, že umožnia ich uplatnenie jednotlivcom a vytvoria procesné pravidlá ich uplatňovania. Takto poskytovaná vnútroštátna súdna ochrana však môže byt' efektívna len vtedy, ak členské štáty vytvoria v rámci svojho vnútroštátneho súdneho systému, systém účinných prostriedkov nápravy spôsobom, ktorý zabezpečí rešpektovanie základného práva na účinnú súdnu ochranu a bude reflektovat' požiadavky vyplývajúce z princípu národnej procesnej autonómie.

V súvislosti so zabezpečovaním základného práva na účinnú súdnu ochranu sú členské štáty a Únia povinné spolupracovat' a kooperovat' pri ochrane únijných práv jednotlivcov. Pre vnútroštátne súdy členských štátov zásada lojálnej spolupráce znamená ich povinnost' poskytnút' účinnú súdnu ochranu práv jednotlivcov vyplývajúcich z práva Únie a pre členské štáty povinnost' prijat' všetky opatrenia potrebné na to, aby si mohli jednotlivci efektívne uplatňovat' svoje práva vyplývajúce z práva Únie súdnou cestou (tzv. aktívna lojálna spolupráca). ${ }^{44}$ Prejavom zásady lojálnej spolupráce je aj princíp vnútroštátnej procesnej autonómie členských štátov pri prijímaní procesnoprávnych noriem a pravidiel, ktorých úlohou je zabezpečit' prístup k spravodlivosti a ochranu práv jednotlivcov. Výkladom čl. 47 Charty v spojitosti s čl. 4 ods. 3 ZEÚ a princípom národnej procesnej autonómie Súdny dvor dospel k záveru, že členský štát je povinný určit’ príslušné súdy a procesné náležitosti týkajúce sa žalôb, ktorými sa jednotlivec domáha ochrany svojich porušených práv vyplývajúcich z práva Únie tak, aby rešpektoval

40 BOBEK, M. - BŘÍZA, P. - KOMÁREK, J.: Vnitrostátní aplikace práva Evropské unie. Praha: C.H. Beck, 2011, s. 218.

41 C-583/22 Inuit Tapiriit Kanatami a i. proti Parlamentu a Rade, ECLI:EU:C:2013:625 alebo C-64/16 Associacao Sindical dos Juizes Portugueses proti Tribunal de Contas, ECLI:EU:C:2018:177.

42 C-33/76 Rewe Zentralfinanz eG proti Landwirschaftskammer für das Saarland, ECLI:EU:C:1976:188.

43 ARNULL, A.: The Principle of Effective Judicial Protection in EU law: An Unruly Horse? European Law Review, 2001, č. 1, s. 51-52.

44 Tamtiež s. 112. 
zásadu efektivity a zásadu ekvivalencie, a na základe takto stanovených predpokladov a náležitosti mohli vnútroštátne súdy jednotlivcom zabezpečit' efektívnu súdnu ochranu ich práv. Právo na účinnú súdnu ochranu práv vyplývajúcich jednotlivcom podliehajúcim súdnej právomoci z práva Únie je potrebné vykladat' $v$ tom zmysle, že nevyžaduje, aby v právnom poriadku členských štátov existovala samostatná žaloba, ktorej hlavným ciel'om by bolo preskúmanie vnútroštátnych ustanovení s právom Únie, ak iné účinné právne prostriedky nápravy, ktoré nie sú menej výhodne ako tie, ktoré sa týkajú podobných vnútroštátnych žalôb, umožňujú posúdit' incidenčne takýto súlad, pričom tieto skutočnosti musí preverit' vnútroštátny súd. ${ }^{45}$

\section{ZÁVER}

Základné právo na účinnú súdnu ochranu poskytuje jednotlivcom vel’mi širokú paletu procesných garancií a záruk na ochranu ich práv vyplývajúcich z práva Únie. Súdnym orgánom Únie prináleží túto ochranu v stanovenom rozsahu a v stanovenej kvalite jednotlivcovi domáhajúcemu sa ochrany svojho porušeného únijného práva poskytnút', v rámci pred nimi prebiehajúcich súdnych konaní. Prijatím Lisabonskej zmluvy došlo aj v systéme účinnej súdnej ochrany $\mathrm{k}$ viacerým významným zmenám. Prvou z nich je kodifikácia základného práva na účinnú súdnu ochranu v čl. 47 Charty, ktorý predstavuje základný pilier súdnej ochrany práv jednotlivcov, v zmysle ktorého sú vnútroštátne súdy a Súdny dvor EÚ povinné zabezpečit' jednotlivcom účinný prostriedok nápravy a spravodlivý proces pred súdom stanovenej kvality v primeranom čase. Druhou významnou zmenou, ktorú priniesla Lisabonská zmluva, je výslovné zakotvenie povinnosti členských štátov ustanovit’ $\mathrm{v}$ oblastiach, na ktoré sa vzt'ahuje právo Únie, prostriedky nápravy potrebné na zabezpečenie účinnej právnej ochrany v texte primárneho práva. Uvedený prístup Únie potvrdzuje snahu Únie približit' sa svojím občanom a zvyšovat' štandard súdnej ochrany ňou priznaných práv jednotlivcom. Práve pri zvyšovaní štandardu účinnej súdnej ochrany zohrávajú vel’mi dôležitú úlohu vnútroštátne súdne orgány členských štátov, ked’že pred nimi prebieha väčšina konaní týkajúcich sa ochrany porušených únijných práv jednotlivcov. Právna úprava základného práva na účinnú súdnu ochranu v práve Únie poskytuje kvalitné predpoklady na zabezpečenie efektívnej vymožitel’nosti únijného práva pred Súdnym dvorom EÚ a vnútroštátnymi súdnymi orgánmi členských štátov, čo prispieva aj k existencii jednotného a komplexného systému súdnej ochrany.

\footnotetext{
Mgr. et Bc. Dominika Becková

Univerzita Pavla Jozefa Šafárika v Košiciach, Právnická fakulta

Ústav medzinárodného práva a európskeho práva

dominika.beckova@student.upjs.sk
}

45 C-432/05 Unibet (London) Ltd a Unibet (International) Ltd proti Justitiekanslern, ECLI:EU:C:2007:163. 